\title{
Determining Emergency Department Nurses' Competence and Preference Levels for Using Ventrogluteal Site in Administering Intramuscular Injections
}

\author{
D Birgül Cerit, 1 (1) Zeynep Emen² \\ ${ }^{1}$ Fundamentals of Nursing Department, Bolu Abant Izzet Baysal University, Faculty of Health Sciences, Bolu, Turkey \\ ${ }^{2}$ Department of Nursing, Bolu Abant Izzet Baysal University Institute of Health Sciences, Bolu, Turkey
}

\section{ABSTRACT}

Objectives: This study was conducted to investigate emergency service nurses' competence levels and preferences for using the ventrogluteal site in administering intramuscular injections.

Methods: This research was designed as a qualitative study. Data for this study were collected from 16 voluntary nurses in a hospital emergency service. Data were collected using a semi-structured interview using the interview form designed by the researchers on April 1-12, 2017. In the analysis of the data, descriptive statistics and content analysis were used.

Please cite this article as: Cerit B, Emen Z. Determining Emergency Department Nurses' Competence and Preference Levels for Using Ventrogluteal Site in Administering Intramuscular Injections. Anatol $J$ Family Med 2020;3(2):107-115.

Address for correspondence: Dr. Birgül Cerit. Fundamentals of Nursing Department, Bolu Abant Izzet Baysal University, Faculty of Health Sciences, Bolu, Turkey

Phone: +90 37425345 20/4773

E-mail:

birgulcerit@yahoo.com.tr

Received Date: 27.05.2019

Accepted Date: 02.01.2020

Published online: 21.08.2020

(C) Copyright 2020 by Anatolian Journal of Family Medicine -

Available online at Www.anatoljfm.org

OPEN ACCESS

Results: In this study, 4 (25.0\%) nurses preferred the ventrogluteal site to administer intramuscular injections, and in general, they had low competence. Eight (66.8\%) of the participating nurses did not utilize ventrogluteal site often due to lack of training or knowledge on the administering intramuscular injections on ventrogluteal site.

Conclusion: Nurses' competences and preference levels for using the ventrogluteal site in administering intramuscular injections were low. Training programs can be organized to meet nurses' training needs, increase their competences and improve the use of the ventrogluteal site in administering intramuscular injections.

Keywords: Emergency Medical Services, intramuscular injections, nurses

\section{INTRODUCTION}

Nurses are responsible for the preparation and safe administration of drugs and monitoring patient responses in all institutions where health care services are provided. ${ }^{[1]}$ It is important that nurses have current and updated information while performing these responsibilities, and they have evidence-based practices. ${ }^{[2]}$ Intramuscular (IM) injections, which form a significant portion of drug administrations, are commonly used by nurses where the drug is administered to the deep muscle tissue under subcutaneous tissue. Due to various risks associated with IM injections, it is necessary for nurses to have sufficient knowledge and competence in this regard, know the application method and the anatomical structure of the site and make the right choices for safe sites. ${ }^{[2,3]}$ If not administered properly, IM injections may lead to serious complications, such as abscess, necrosis, hematoma, ecchymosis, infections, pain, periostitis, vascular and nerve injury. Identifying and selecting the right site is important in preventing these complications and for administering injections in a safe site. ${ }^{[3-8]}$ 
The ventrogluteal (VG) site, which is highly preferred for safe injections recently, was first used by Hochstetter as an IM injection area at the beginning of the $1950 \mathrm{~s} .{ }^{[1,7]}$ Since the VG site includes thick gluteal muscles composed of gluteus medius and gluteus minimus muscles, this site can be safely used for all individuals. ${ }^{[5,7,9,10]} \mathrm{VG}$ site is regarded as the most reliable and least painful IM injection site because this site is distant from large blood vessels and nerves, positioning the patients' is easy, the subcutaneous layer is thin. Thus, the possibility of administering the drug to subcutaneous tissue is low and the risk of hematoma formation is minimal. ${ }^{[1,5,7,11]}$ It was reported in a previous study that complications may arise in the VG site only due to reaction to the administered drug. ${ }^{[6]}$ In addition, it is suggested that the VG site should be used as the first choice in IM injections since it is possible to perform safe site detection because measurements are carried out by palpating bone structures and the fecal contamination risk is low due to the distance from the rectum. ${ }^{[1,5,7,11-14]}$

When studies on the topic are examined, it is seen that nurses mostly prefer the dorsogluteal (DG) site for IM injections and rarely use the VG site. ${ }^{[13,15-19]} \mathrm{A}$ study that assessed IM injection practice found that $60 \%$ of the nurses used the DG site when injecting, and $78.2 \%$ never used the VG site. ${ }^{[16]}$ Studies investigating the reasons for nurses' lack of VG site use based on nurse statements determined that most of the nurses did not have enough information about VG site, that it was very difficult to give up their habits, that they had difficulty adapting, that they thought they could harm the patient and did not believe the site was safe. ${ }^{[15,17,20]}$ They had difficulty in identifying the anatomic site. ${ }^{[21]}$ However, literature emphasizes that the VG site should be preferred to the DG site for safe IM injections. ${ }^{[1,22,23]}$

A study conducted with the emergency, intensive care and inpatient service nurses assessed the effects of training on IM injections to VG site and showed that the rate of nurses using DG site before training decreased from $76.5 \%$ to $48.1 \%$ after four months of training and the rate of using VG site increased to $34.6 \%$ from $7.4 \%$. Based on this study, nurses' preference level and competence in using VG site increased with the training. ${ }^{[21]}$ In undergraduate nursing courses, the VG site is emphasized as the first option rather than as an alternative to the DG site in selecting IM injection administration sites. ${ }^{[13,24]}$ Also, many textbooks advise using the VG site as the first option for IM injections. However, despite the extensive emphasis and demonstration of the VG site at schools, it appears that students rarely observe this practice at hospitals and therefore, cannot transfer it. ${ }^{[13,24]}$ Nurse attitudes as role models in safe injec- tion practices are highly significant in raising awareness for administering injections to the VG site so that students can demonstrate and reinforce the theoretical skills in practical training and clinical settings.

Nurses lack sufficient knowledge and skills concerning the use of the VG site. Thus, they are reluctant to administer injections using this site. ${ }^{[2,15,19]}$ Although the VG site has been advocated as the first option for IM injections by nurses, the DG site, vastus lateralis and deltoid site are generally used despite known possible risks. . $^{[6,11,18,22,24]}$ It is crucial to ensure that IM injections are safely performed, evidence-based practices are used, and safe practices are commonly used by all nurses. ${ }^{[13,24]}$ Especially in emergency services, where the number of patients who require injections is considerably higher, the sensitivity of this issue is more evident. ${ }^{[25]}$ In this context, it is important to select a safe site for injections in emergency departments to prevent complications. ${ }^{[1,25]}$ In the light of this, the present study aimed to investigate emergency department nurses' competence and preference levels in using the VG site for injections.

\section{METHOD}

\section{Design}

This research was designed as a qualitative study.

\section{Study Group}

Study participants consisted of 16 voluntary nurses employed in the emergency department of a university hospital.

\section{Data Collection}

Research data were obtained using a semi-structured interview using the interview form prepared by the researchers on April 1-12, 2017. An interview was held with two nurses from another hospital to test how long the interview would last and the intelligibility of the interview questions. Interviews, each of which lasted approximately 25 minutes, were in writing recorded by the second researcher. The interviews were conducted face to face in a private room in the emergency department. Only the interviewer and the participant participated in the interviews. The interviewer is a female nurse working in the emergency department and continuing to master program in nursing at the same time. Participants recognize the interviewer as a colleague. Participants were told that their names would be kept confidential and each nurse was given a code name to be interviewed. At the end of the interviews, it was observed that informative information about this research was obtained. Transcripts were not returned to participants for comment or correction. The interview form included the following questions: "Do 
you primarily prefer the VG site for IM injections? Why?," "Have you previously administered injections into the VG site?," How do you determine the anatomic site in VG injections?".

\section{Data Analysis}

Content analysis was used data analysis in this study. Data obtained from the nurses were typed digitally; texts related to each question were codified after researchers read them one by one and the related codes were combined to generate themes. The data were presented as frequency, percentage, mean, standard deviation, median, minimum and maximum.

\section{RESULTS}

The findings of the descriptive characteristics of the participants in this study are as follows: 12 (75.0\%) of the participants were female, and $4(25.0 \%)$ were male, with a mean age of $30.2 \pm 7.1$ years and 16 (100.0\%) participants had bachelor's degrees. Five (31.0\%) of the participants had 1-5 years, $6(38.0 \%)$ had $6-10$ years, and $5(31.0 \%)$ had $11-15$ years' work experience. The median years of experience at the emergency service was $5.5(0.2-11.0)$ years.

The findings of this research are presented below in themes:

\section{Preference Level for Using VG Site for IM Injections Injection into the VG site and status of preferring the VG site}

Table 1 displays the nurses' preference level for using the VG site for IM.

The nurses were asked whether they had previously administered injections in the VG site and the status of preferring the VG site. Ten (62.5\%) of the participants stated that they used the VG site for injections, while 6 (37.5\%) nurses stated that they had never used this site for injections before. Twelve (75.0\%) of the nurses stated they did not primarily prefer the VG site for IM injections. Nurses reported usually administering three injections per week, frequently selecting DG and deltoid sites but rarely the VG site. A nurse said: "We frequently use deltoid because it is necessary to administer tetanus vaccinations less than 2 cc to patients after acute trauma." (Interview N2)

\section{Reasons for using the VG site in IM injections or lack of use Reasons for preferring the VG site in IM injections}

Four (25.0\%) nurses stated preference for the VG site for IM injections. Reasons for preferring the VG site in the participants' own words: "This site is safer and less painful." (Interview N2)
Table 1. Nurses' preference level for using ventrogluteal site for intramuscular injections

Theme I: Preference level for using VG site

Sub-theme I: Injection into the VG site and n (\%) status of preferring the VG site Injection into the VG site $(n=16)$

I used VG site for injections

I had never used VG site for injections

Status of preferring the VG site $(n=16)$

I don't primarily prefer the VG site

I primarily prefer the VG site

$4(25.0)$

Theme II: Reasons for using the VG site in

IM injections or lack of use $(n=4)$

VG site is safer and less painful

$1(25.0)$

VG site is far from the sciatic nerve

$1(25.0)$

The largest muscle is located in the VG site,

and absorption is better

It is easy to position patients

Reasons for not preferring the VG site $(n=12)$

I did not receive any training about the VG site

It is easier to locate the DG site

I am more familiar with other sites

I have difficulty in identifying the injection site

Positioning the patients is more difficult for the VG site

$1(8.3)$

VG: Ventrogluteal; DG: Dorsogluteal.

"It is far from the sciatic nerve." (Interview N4)

"Because it is easy to position patients." (Interview N13)

"The largest muscle is located here, and absorption is better." (Interview N11)

However, 12 (75.0\%) of the nurses stated they did not prefer the VG site for injections.

\section{Reasons for not preferring the VG site in IM injections}

When the definitions provided by nurses for not selecting the VG site for IM injection were examined, it was found that nurses did not prefer this site because $8(66.8 \%)$ of the nurses did not receive training and did not know much about the VG site.

One of the participants in this regard said: "I do not prefer the VG site for injections because I do not have information about the VG site. I know about other muscle regions and I use them." (Interview N3)

Another nurse said: "I do not prefer it because this technique did not exist when I took my training/l prefer to apply the tech- 
nique I am familiar with because otherwise, I will feel insufficient concerning knowledge." (Interview N10)

The other 4 (33.2\%) participants indicated that they prefer not to administer injections to the VG site. One (8.3\%) of the participants said it was easier to locate the DG site, the other 1 (8.3\%) participant reported it was more familiar with other sites, 1 (8.3\%) other nurse said it had difficulty in identifying the injection site and the last 1 (8.3\%) reported it also thought that positioning the patients is more difficult in VG site.

\section{Nurses' Competence Level for VG Site Injections}

Nurses' competence level for VG site injections is shown in Table 2. In this section, nurse competencies to administer injections in VG site are explained under the following themes: patient positioning, identifying the site, cleaning the injection area, determination of pinching up and stretching the tissue and angle of injection, aspiration status, muscle used in VG site, amount of administered drug and duration of the application, supporting the injection site and age groups for VG injections.

\section{Patient Positioning}

Seven (44.2\%) of the nurses stated that they did not know how to position patients to administer injections in the VG site. One of the participants said: "I have no knowledge of this since I have never practiced it." (Interview N3)

Two (12.6\%) of the nurses stated they would use the supine position, $4(24.6 \%)$ nurses said they would position the patient prone and $3(18.6 \%)$ nurses opted for the lateral position.

\section{Site Identification}

Twelve (75.2\%) of the nurses said that they did not know how to identify the site when administering injections in the VG site. Four (24.8\%) nurses explained the site identification. The following quotes illustrate these findings:

"[...] The palm is placed on the trochanter, the index finger is stretched towards the iliac protrusion, and the middle finger is stretched backwards and the injection is administered in the site located between these two fingers." (Interview N2)

"We stand to the left of the patient and put the right palm on the trochanter. The index finger is placed on crista iliaca anterior superior and the middle finger stretched back. The injection is administered in the area located there." (Interview N9)

"The palm is placed at the start of the the femur, the index finger is placed on the bone protrusion in front, [...... the middle finger is stretched as far as it goes, and injection is administered in the area located in the middle." (Interview N13)

"We place our palms on the femur, we put the thumb towards the direction of the pubic, the index finger on iliac protrusion and stretch the middle finger; we administer the injection on centroid formed between this triangle." (Interview N14)

\section{Cleaning the Injection Area}

Thirteen (81.2\%) of the nurses reported that wiping the injection area radially from the inside out with alcohol swab while 3 (18.8\%) participants reported using Batticon solution. A participant said:

"Before injections, I wipe the area in circular motions with alcohol-soaked cotton and let it dry it for 1-2 seconds [......." (Interview N13)

\section{Determination of pinching up and stretching the tissue and angle of injection}

Twelve (75.0\%) of the nurses stated they stretched the tissue; $2(12.6 \%)$ nurses said they pinched up the tissue and $1(6.2 \%)$ nurse reported they stretched or pinched it up based on patient's weight while $1(6.2 \%)$ nurse reported having no knowledge concerning the question. Thirteen $(81.2 \%)$ of the nurses reported using a $90^{\circ}$ angle, $2(12.6 \%)$ nurses reported $45^{\circ}$ angle while 1 (6.2\%) nurse reported having no knowledge on angles used in injections.

One of the participants in this regard said: "l use a $90^{\circ}$ angle for patients with normal weight, and I use $90^{\circ}$ angle by pinching up the tissue for cachectic patients." (Interview N9)

Another nurse in this regard said: "Usually with $90^{\circ}$ if the patient is weak, I will do it with a lower angle." (Interview N14)

\section{Aspiration status}

Sixteen (100.0\%) of the nurses reported using aspiration before administering injections.

A participant said: "[...] if there is blood, the drug is not administered, because it shows we are in the vessel." (Interview N14)

\section{Amount of administered drug and duration of application}

Seven (44.2\%) of the nurses stated that they did not know the amount of medication administered in the VG site and the duration of application. Other participants' views are provided below:

\section{"4-5 cc in 1 minute." (Interview N1)}

"6 cc in 3 seconds." (Interview N2) 


\section{Table 2. Nurses' competence level for ventrogluteal site injections}

Theme II: Competence level for ventrogluteal site injections

\section{Sub-theme I: Patient positioning}

I don't know

Supine

Prone

Lateral

Sub-theme II: Site identification

I don't know.

The palm is placed on the trochanter, the index finger is stretched towards the iliac protrusion, and the middle finger

is stretched backwards and the injection is administered in the site located between these two fingers

The palm is placed on the trochanter, the index finger is placed on crista iliaca anterior superior and the middle finger

stretched back. The injection is administered in the area located there

The palm is placed at the start of the into the femur; the index finger is placed on the bone protrusion in front, the middle

finger is stretched as far as it goes, and injection is administered in the area located in the middle

The palm on the femur, we put the thumb towards the direction of the pubic, the index finger on iliac protrusion and

stretch the middle finger; we administer the injection on centroid formed between this triangle

\section{Sub-theme III: Cleaning the injection area}

From the inside out with alcohol swab

From the inside out with batticon solution

\section{Sub-theme IV: The tissue position and angle of injection}

\section{The tissue position}

I stretched the tissue

I pinched up the tissue

I stretched or pinched it up based on patient's weight

I don't know

\section{Angle of injection}

$90^{\circ}$ angle

$45^{\circ}$ angle

I don't know

Sub-theme V: Aspiration status

I use aspiration

Sub-theme VI: Amount of administered drug and duration of application

I don't know

3-4 cc/30 sec

3-5 cc /10-20 sec

3-5 cc /3-4 sec

3-10 cc/ I don't know the time

$4-5 \mathrm{cc} / 60 \mathrm{sec}$

$5 \mathrm{cc} / \mathrm{I}$ don't know the time

$5 \mathrm{cc} / 60 \mathrm{sec}$

$6 \mathrm{cc} / 3 \mathrm{sec}$

$10 \mathrm{cc} / 5-10 \mathrm{sec}$

Sub-theme VII: Supporting injection site

I support it with a dry cotton

Sub-theme VIII: Muscle used in the VG site 
Table 2. CONT.

\begin{tabular}{|c|c|}
\hline \multicolumn{2}{|c|}{ Sub-theme IX: Age groups for the VG injections } \\
\hline I don't know & $9(56.4)$ \\
\hline 3 years and older & $2(12.6)$ \\
\hline Over 5 years & $1(6.2)$ \\
\hline 16 years and older & $1(6.2)$ \\
\hline 20 years and older & $1(6.2)$ \\
\hline
\end{tabular}

"3-5 cc in 3-4 seconds." (Interview N4)

"3-10 cc... but I do not know the duration." (Interview N5)

"5 cc... but I do not know the duration" (Interview N6)

"5 cc in 1 minute." (Interview N7)

"3-4 cc in half a minute." (Interview N9)

"10 cc in 5-10 seconds." (Interview N11)

"3-5 cc in 10-20 seconds." (Interview N13)

\section{Supporting the injection site}

Sixteen (100.0\%) of the nurses indicated that they padded the injection are with dry cotton after removing the needle. One (6.2\%) of the participants in this regard said: "padding with cotton while supporting the site with the other hand." (Interview N9)

\section{The muscle used in the VG site}

Nine (56.4\%) of the nurses said that they did not know which muscles used when they administered VG injections. Among other participants, 2 (12.6\%) nurses stated using the gluteus medius, 3 (18.6\%) nurses reported using gluteal muscles, 1 (6.2\%) nurse gluteus minimus and the last 1 (6.2\%) nurse gluteus maximus.

\section{Age groups for the VG injections}

Nine (56.4\%) of the nurses stated that they had no knowledge of the most suitable age group for using the VG site for injections. Among other participants, 1 (6.2\%) nurse stated it is suitable for patients over five years, 1 (6.2\%) nurse reported it is suitable for patients sixteen years and older, 1 (6.2\%) nurse reported it is suitable for patients over fifteen years, 2 (12.6\%) nurses reported it is suitable for patients three years and older, 1 (6.2\%) nurse reported its use for adults and other $1(6.2 \%)$ nurse stated it is suitable for patients 20 years and older.

\section{DISCUSSION}

In the light of literature, the findings obtained in this study are discussed under two headings.

\section{Emergency service department nurses' level of prefer- ence for using the VG site in IM injections}

The study determined that nurses used the deltoid site and DG site most frequently for IM injections and preferred the VG site less. Based on nurse statements obtained in the study, the deltoid site appears to be used for posttraumatic tetanus vaccinations. Other than this site, nurses were found to often use the DG site for other drug administrations. The study conducted by Floyd and Meyer to identify the IM injection site preferred by nurses supports the findings of the current study and determined that nearly all nurses who participated in the research used the DG site for injections while only a few administered injections to VG site. ${ }^{[18]}$ Gülnar and Özveren's study which investigated the effect of nurse training on administering IM injections to VG site, found that while use of DG site for injections was prevalent before training, there was a high increase in the frequency of using the VG site for injections after training. ${ }^{[21]}$ Similar to the findings of this study, another study aimed at determining emergency, intensive care and inpatient service nurses' level of knowledge in IM injections to VG site reported that the most frequently used injection site was the DG site. ${ }^{[15]}$ Based on study findings, it can be argued while it is not regarded to be safe area for injections, the DG site is the first preferred site for IM injections. However, literature reports that the VG site should be the first preferred site for IM injections for safe administrations. ${ }^{[1,26,27]}$

In this study, most of the nurses reported lack of preference for the VG site because they did not know the VG site and had difficulty identifying it and they found it easier to administer IM injections to DG site. Gülnar and Çalışkan's findings that, "nurses did not use the VG site for injections, 
preferred the DG site and had difficulty in detecting the VG site due to lack of knowledge" are consistent with the findings obtained in the present study. ${ }^{[15]}$ Also, parallel to the findings of this study, the study conducted by Wyaden et al. found that nurses did not prefer the VG site because they thought the VG site was not as safe as the DG site, determining the VG site was difficult anatomically and injecting between the index finger and middle finger was difficult. ${ }^{[20]}$ Greenway et al. also reported that nurses did not want to use this site because of the difficulty of detecting the VG site. ${ }^{[26]}$ Another reason why nurses did not use the VG site for IM injection was related to lack of patient experience and reluctance for injections in VG site which may result in believing that they were injected in the wrong site. ${ }^{[13,18,24]}$ This misperception also affects student nurses undertaking their clinical applications. After student nurses acquire theoretical knowledge, they apply VG injections in the skills lab. In this sense, the education system tries to present student nurses with appropriate educational experiences. However, since these practices are not supported in the clinic, they can be forgotten without turning into actual skills. It is important that nurses use the VG injection clinically as an appropriate role model. When nurses practice IM injections at the VG site as professional members of the profession, patient perceptions will differentiate, and student nurses or nurses will be able to administer IM injections at the VG site without patient resistance. Also, student nurses' behaviors will be reinforced in this regard. Therefore, it is important in that nurses perform accurate and reliable practices as student as well.

\section{Emergency service department nurses' competence in us- ing IM injections in the VG site}

In this study, the majority of the nurses stated that patients could be given supine, facedown and lateral positions for VG injections. Similar to the finding of this study, literature review shows that that patient may be given supine, facedown or lateral positions in identifying the VG site. ${ }^{[1,5,12,27]}$ Easy and alternative patient positioning allows using the VG site for IM injections and provides comfort in injecting patients with limited mobility. ${ }^{[1,5]}$ In addition, when appropriate positioning is provided to relax muscles during injection, patients will feel less pain. ${ }^{[6,20]}$ In this regard, it is positive that the nurses involved in this study had knowledge of patient positioning for VG injections.

Most nurses in this study stated that they did not know how to identify the site when administering injections in the VG site. Previous studies also point to difficulty in this regard. $[15,19,20,26]$ However, bone protrusions which can be felt easily by hand make site identification easy in VG injections and ensure safe injections. ${ }^{[26]}$ The core nursing school's curriculum in Turkey describes IM injection practices to VG site in process steps and these steps are demonstrated in lab practices where nursing students are given opportunities to practice. Based on research findings, it can be argued that nurses continue traditional practices, in other words, they continue using the DG site and since they display no preference for the VG site for IM injections, their theoretical knowledge and skills regress.

Most nurses in this study stated that they did not know the amount and duration of the drug and which muscles the drugs are administered during VG injections. The amount of drugs that can be administered at one time to VG site composed of gluteus medius and gluteus minimus muscles is $5 \mathrm{ml}$ for adults and $2-3 \mathrm{ml}$ for children, elderly and cachectic patients..$^{[1,6,14]}$ It is necessary to administer $1 \mathrm{ml}$ of the injected drug continuously and slowly in a manner that can be transmitted in 10 seconds. This pace allows extension of muscle fibers and the propagation of the injected drug towards the muscle tissue. ${ }^{[1,5]}$ The findings in this study showed that nurses have no knowledge of muscles, amount and duration of drug to administer IM injections in the VG site is assessed negatively concerning safe injection practices and complications that may arise due from injections.

Most nurses in this study expressed that they did not know which age group the VG site could be used for. The VG site can be used in adults, children older than seven months and in cachectic patients. ${ }^{[14]}$ A study conducted by GüneşYapucu et al. to examine the reliability of the method used to determine the VG site found that the method was reliable in all subjects with a body mass index (BMI) of 18.529.9 , it was reliable in many subjects with a BMI of 30-39.9 and the method was unreliable in all subjects 40 years and older. ${ }^{[16]}$ Based on research findings, it can be argued that it is important for nurses to know the age to properly determine the VG site and to complete the injection as desired.

Most nurses in this study were found to have sufficient knowledge and skills concerning administering IM injections in the VG site, such as cleaning the area, stretching the tissue, using a $90^{\circ}$ angle for injections, undertaking the process of aspiration by pulling the syringe piston back before injections and padding the injected area with dry cotton pads, and VG injection. Similar to the present research findings, the study conducted by Gülnar and Çalışkan also found that most of the nurses expressed IM injection process steps successfully, such as "before administering the drug when the tissue is penetrated, blood check is done by pulling the pistol back", "site of injection is cleaned in cir- 
cular movements of $5 \mathrm{~cm}$ with an antiseptic pad" and "the drug is injected after the antiseptic solution is dried."[15] Research findings purport that successful implementation of the above steps during IM injections will decrease the risk of complications for patients and the risk of experiencing painful injections.

\section{CONCLUSION}

In light of the findings obtained in this study, it was concluded that most of the emergency service department nurses in this study did not prefer using the VG site and they had low competence about patient positioning, site identification, maximum amount of drugs to be used in the VG site and the duration of administration, the muscles that are used and the age groups for VG administrations.

"This study was presented as a oral presentation at the 5th International and 16th National Nursing Congress held in Ankara on 5-8 November 2017".

\section{Disclosures}

Peer-review: Externally peer-reviewed.

Conflict of Interest: None declared.

Ethics Committee Approval: Ethical approval for this study was obtained from the university ethics committee (Gazi University Ethics Commission - Research code no. 2017-50) and from the hospital where this study was conducted. Written consent was obtained from all participants.

Authorship Contributions: Concept - B.C., Z.E.; Design - B.C.; Supervision - B.C., Z.E.; Materials - B.C., Z.E.; Data collection \&/or processing - Z.E., B.C.; Analysis and/or interpretation - B.C., Z.E.; Literature search - B.C., Z.E.; Writing - B.C., Z.E.; Critical review - B.C.

\section{REFERENCES}

1. Kaya N, Palloş A. Parenteral drug applications. In: Atabek Aştı T, Karadağ A, editors. Fundamentals of Nursing: Nursing Science and Art. İstanbul: Akademi Basın ve Yayıncılık; 2013. p. 786-91.

2. Karacaoğlu-Vicdan A, Ecevit-Alpar ş. The use of the ventrogluteal region in intramuscular injection. Yıldırım Beyazıt Üniversitesi Sağlık Bilimleri Fakültesi Hemşirelik E-Dergisi 2015;3(2):56-61.

3. Dinç L. Parenteral drug. In: Atabek-Aşti T, Karadağ A, editors. Clinical Nursing Skills and Methods. Adana: Nobel Kitabevi; 2010. p. 693-761.

4. Kadıoğlu H. Injection-Induced Sciatic Nerve Injury: Is It A Complication? AÜTD 2004;36:65-70.

5. Berman A, Snyder SJ, Frandsen G. Kozier \& Erb's Fundamentals of Nursing. 10th ed. England: Pearson Education Limited; 2016.
6. Nicoll LH, Hesby A. Intramuscular injection: an integrative research review and guideline for evidence-based practice. Appl Nurs Res 2002;15(3):149-62.

7. Potter P, Perry A, Stockert $P$, Hall A. Fundamentals of Nursing. 8th ed. Canada: Elsevier Health Sciences; 2013.

8. Şanlıalp A. Evaluation of dorsogluteal and ventrogluteal region selection and nursing practice for intramuscular injections (dissertation). Denizli: Pamukkale Univ. 2013.

9. Güneş Yapucu Ü, Zaybak A, Tamsel S. Ventrogluteal Bölgenin Tespitinde Kullanilan Yöntemin Güvenirliğinin İnc. Cumhuriyet University Journal of Nursing 2008;12(2):1-8.

10. Emre Yavuz D, Karabacak Ü. Intramüsküler Enjeksiyonda Neden Ventrogluteal Bölgeyi Tercih Etmeliyiz? Hemşirelikte Araştırma Geliştirme Dergisi 2011;2:81-8.

11. Greenway K, Merriman C, Statham D. Using the ventrogluteal site for intramuscular injections. Learn Disabil Pract 2006;9:34-7.

12. Craven RF, Hirnle CJ. Fundamentals of nursing. 6th ed. Philadelphia: Wolters Kluwer Lippincott; 2009.

13. Kara D, Uzelli D, Karaman D. Using ventrogluteal site in intramuscular injections is a priority or an alternative? International Journal of Caring Sciences 2015;8(2):507-13.

14. Hopkins U, Arias C. Large-volume IM injections: A review of best practices intramuscular injections offer improved treatment adherence, ease in monitoring of adverse effects and multiple administration sites. Oncology Nurse Advisor 2013;10:32-7.

15. Gülnar E, Çalışkan N. Hemşirelerin Ventrogluteal Bölgeye İntramüsküler Enjeksiyon Uygulamasına Yönelik Bilgi Düzeylerinin Belirlenmesi. DEUHYO ED 2014;7(2):70-7.

16. Güneş Yapucu Ü, Zaybak A, Biçici B, Çevik K. Hemşirelerin intramüsküler enjeksiyon işlemine yönelik uygulamalarının incelenmesi. Atatürk Üniversitesi Hemşirelik Yüksekokulu Dergisi 2009;12(4):84-90.

17. Kilic E, Kalay R, Kilic C. Comparing applications of intramuscular injections to dorsogluteal or ventrogluteal regions. J Exp Integr Med 2014;4(3):171-4.

18. Floyd S, Meyer A. Intramuscular injections--what's best practice?. Nurs N Z 2007;13(6):20-2.

19. Tuğrul E, Denat Y. Hemşirelerin Ventrogluteal Alana Enjeksiyon Uygulamaya İlişkin Bilgi, Görüş ve Uygulamaları. DEUHYO ED 2014;7(4):275-84.

20. Wynaden D, Landsborough I, McGowan S, Baigmohamad Z, Finn M, Pennebaker D. Best practice guidelines for the administration of intramuscular injections in the mental health setting. Int J Ment Health Nurs 2006;15(3):195-200.

21. Gülnar E, Özveren H. An evaluation of the effectiveness of a planned training program for nurses on administering intramuscular injections into the ventrogluteal site. Nurse Educ Today 2016;36:360-3.

22. Small SP. Preventing sciatic nerve injury from intramuscular 
injections: literature review. J Adv Nurs 2004;47(3):287-96.

23. Mishra $P$, Stringer MD. Sciatic nerve injury from intramuscular injection: a persistent and global problem. Int J Clin Pract 2010;64(11):1573-9.

24. Hunter J. Intramuscular injection techniques. Nurs Stand 2008;22(24):35-40.

25. Başol N, Çelik Y, Ayan M, Esen M, Koç I, Savaş AY, et al. Acil Servis Yoğunluğunun Bir Sebebi Olan Enjeksiyon Amaçlı
Başvuruların Değerlendirilmesi. Gaziosmanpaşa Üniversitesi Tıp Fakültesi Dergisi 2014;6:258-68.

26. Greenway K. Using the ventrologluteal site for intramuscular injection. Nurs Stand 2004;18(25):39-42.

27. Taylor CR, Lillis C, Lemone P, Lynn P. Fundamentals of nursing: the art and science of nursing care. 7th ed. Philadelphia: Lippincott Williams \& Wilkins; 2011. 